\title{
The Flagellar Sigma Factor FliA Is Required for Dickeya dadantii Virulence
}

\author{
Courtney E. Jahn, ${ }^{1}$ David K. Willis, ${ }^{1,2}$ and Amy O. Charkowski ${ }^{1}$ \\ ${ }^{1}$ Department of Plant Pathology, University of Wisconsin, and ${ }^{2}$ Vegetable Crops Research Unit, United States Department \\ of Agriculture-Agricultural Research Service, Madison, WI 53706, U.S.A.
}

Submitted 11 April 2008. Accepted 7 July 2008.

\begin{abstract}
The genome sequence of the Enterobacteriaceae phytopathogen Dickeya dadantii (formerly Erwinia chrysanthemi) revealed homologs of genes required for a complete flagellar secretion system and one flagellin gene. We found that $D$. dadantii was able to swim and swarm but that ability to swarm was dependent upon both growth media and temperature. Mutation of the $D$. dadantii fliA gene was pleiotropic, with the alternate sigma factor required for flagella production and development of disease symptoms but not bacterial growth in Nicotiana benthamiana leaves. The flagellar sigma factor was also required for multiple bacterial phenotypes, including biofilm formation in culture, bacterial adherence to plant tissue, and full expression of pectate lyase activity (but not cellulase or protease activity). Surprisingly, mutation of $f l i A$ resulted in the increased expression of avrL (a gene of unknown function in $D$. dadantii) and two pectate lyase gene homologs, pelX and ABF0019391 . Because FliA is a key contributor to virulence in D. dadantii, it is a new target for disease control.
\end{abstract}

The Enterobacteriaceae phytopathogen Dickeya dadantii causes wilting and soft rot in a wide range of plants, including ornamental plants and economically important vegetable crops (Ma et al. 2007). D. dadantii produces a variety of cell-walldegrading enzymes, such as pectate lyases (Pels), polygalacturonases, and cellulases. These enzymes cause plant tissue maceration and are the primary pathogenicity factor of this pathogen (Barras et al. 1994). However, many other factors are important for pathogenicity. Iron scavenging, for example, allows for systemic attack, weakening the plant by transferring iron from plant cells to chrysobactin, a $D$. dadantii siderophore (Enard et al. 1988; Persmark et al. 1989, 1992). Other virulence factors include lipo- and exopolysaccharide production (Condemine et al. 1999; Schoonejans et al. 1987), the type III secretion system (T3SS), and proteins involved in environmental sensing and resistance against plant defense (Llama-Palacios et al. 2003; Lopez-Solanilla et al. 1998).

We have observed that $D$. dadantii cells are motile in diseased plant tissue (unpublished observations) but whether the production of secondary metabolites, enzymes, and secretion systems that contribute to virulence is coordinated with motility is unknown. As yet, flagellar genes have not been shown to

Corresponding author: A. O. Charkowski; Telephone: +1.608.262.7911; Fax: +1.608.263.2626; E-mail: amyc@plantpath.wisc.edu

This article is in the public domain and not copyrightable. It may be freely reprinted with customary crediting of the source. The American Phytopathological Society, 2008. contribute to virulence for this genus. Many phytopathogenic bacteria are motile by means of flagella and this motility contributes to virulence (Chesnokova et al. 1997; Mulholland et al. 1993; Panopoulos and Schroth 1974; Tans-Kersten et al. 2001). In animal pathogens, such as Escherichia coli and Salmonella spp., flagella are also an important factor in hostparasite interactions. Approximately 50 genes are known to be involved in constructing and operating the flagellar apparatus, and its transcription is coordinated by a complex regulatory hierarchy that includes both positive and negative regulators (Macnab 1996). Flagella operons are transcribed in three temporal classes: early, middle, and late. The early genes are included in the master flagellar operon, $f l h D C$, that directs transcription of the middle and some of the late genes. The middle operons encode structural and assembly proteins required for the biosynthesis of the flagellar basal body and hook. The gene fliA encodes an alternative transcription factor, $\sigma^{28}$, which is specifically required for class III promoter transcription. Class III promoters control genes that encode for later products in flagella assembly, including the external filament, the flagella motor, and chemotaxis genes (Chilcott and Hughes 2000; Macnab 1996). Mutations in fliA lead to aborted flagella biosynthesis that stalls after formation of the flagella basal body and hook (Chilcott and Hughes 2000; Macnab 1996).

In some bacterial species, the same proteins that regulate expression of flagella genes also regulate virulence factors. There are many Enterobacteriaceae species that coregulate flagella and the T3SS. For example, in Yersinia enterocolitica, the T3SS is downregulated by FliA, probably by downregulation of the T3SS transcriptional activator virF (Horne and Pruss 2006). In contrast, the T3SS in Salmonella typhi is upregulated by FliA (Eichelberg and Galan 2000). FliA also upregulates the T3SS in S. typhimurium but to a lesser extent than is seen in S. typhi (Eichelberg and Galan 2000). These differences show that the regulatory effects of FliA on virulence genes cannot yet be predicted solely based upon comparison with related genera; rather, they must be experimentally determined.

Flagella are used for both swimming and swarming motility. Individual swimming cells perceive a chemical signal via methyl-accepting chemotaxis proteins, triggering a chemotactic response to the signal (Yi et al. 2000). Swarming is characterized by movement of bacteria in tight groups of bound cells through bacterial-produced slime on semisolid surfaces (Harshey 2003). Swarming motility requires bacteria to undergo a differentiation process that causes the cells to become filamentous and hyperflagallate (Allison and Hughes 1991; Fraser and Hughes 1999). Repeated events of swarmer differentiation, swarming movement, and reversion to short cells give rise to concentric rings as populations of bacteria colonize a rich solid surface (Shapiro 1998). Some species may also form 
elaborately shaped colonies with dendritic extensions, but this does not occur with all bacterial species that are capable of swarming.

Because we have observed that $D$. dadantii cells are motile in diseased plant tissue, we hypothesized that $D$. dadantii fliA would be required for full virulence and that, as in related pathogens, it will affect expression of genes in addition to flagellar genes. In this work, we found that a $D$. dadantii mutant lacking fliA is reduced in virulence, reduced in ability to adhere to plant tissue, reduced in Pel activity, and affected in biofilm development.

\section{RESULTS}

The D. dadantii flagellar operon structure is encoded in one locus and the flagellin includes the flg22 sequence.

Like E. coli, D. dadantii produce peritrichous flagella; however, unlike some other Enterobacteriaceae, D. dadantii encodes only one type of flagella and one type of flagellin. The flagella regulatory proteins found in other Enterobacteriaceae are conserved in $D$. dadantii, including the master regulator FlhD/FlhC and the alternate sigma factor, FliA. The order of the genes within each operon is similar to $E$. coli; however, the arrangement in the chromosome differs, with flagellar operons in E. coli and S. enterica Typhimurium in three loci and flagellar operons in D. dadantii, Pectobacterium carotovorum, P. atrosepticum, and $Y$. enterocolitica in a single gene cluster (Bell et al. 2004; Horne and Pruss 2006) (Fig. 1A). The Pectobacterium spp., unlike $D$. dadantii, encode a second flagellin homolog elsewhere in the chromosome.

A 22-amino-acid portion (flg22) of the flagellin FliC may be recognized by plants via FLS2 as a pathogen-associated molecular pattern (Morden et al. 1991), resulting in elicitation of plant defenses (Chinchilla et al. 2006; Felix et al. 1999; GomezGomez and Boller 2002; Hayashi et al. 2001). The flg22 sequences were compared among pathogenic bacteria to determine if the amino acids required for plant perception were present in $D$. dadantii. All five key amino acids previously identified as required for defense elicitation were found in all Enterobacteriaceae flagellin proteins examined; thus, plants encoding FLS2 would be predicted to recognize and respond to Enterobacteriaceae species. All of the Enterobacteriaceae flg22 sequences examined are identical except for that of $D$. dadantii and two of the six Pectobacterium flagellin homologs which, based on BLAST search of the National Center for Biotechnology Information protein database, encode flg22 sequences unique among all sequenced flagellins (Fig. 1B).

\section{D. dadantii motility is affected by growth media and temperature.}

Bacterial motility can be observed in media with low levels of agar, with 0.2 to $0.4 \%$ agar typically used for measuring swimming and 0.45 to $0.8 \%$ for swarming (Burkart et al. 1998; Harshey 1994; Niu et al. 2005). In some species, swarming bacteria form elaborate dendritic colonies but Enterobacteriaceae species often do not form elaborate swarming patterns (Burkart et al. 1998; Julkowska et al. 2004). We compared four growth media-tryptic soy agar (TSA), Luria-Bertani agar (LBA), salt-optimized broth plus $2 \%$ glycerol (SOBG), and swarming media (SM) - at two different agar concentrations $(0.3 \%$ for swimming and $0.5 \%$ for swarming) to examine $D$. dadantii motility. We found that $D$. dadantii 3937 swam in all four media at temperatures ranging from 20 to $36^{\circ} \mathrm{C}$ (not shown). In contrast, $D$. dadantii swarmed only on TSA and SM but not in LBA or SOBG (Fig. 2). Temperature differentially affected motility on these media, with bacteria swarming

A
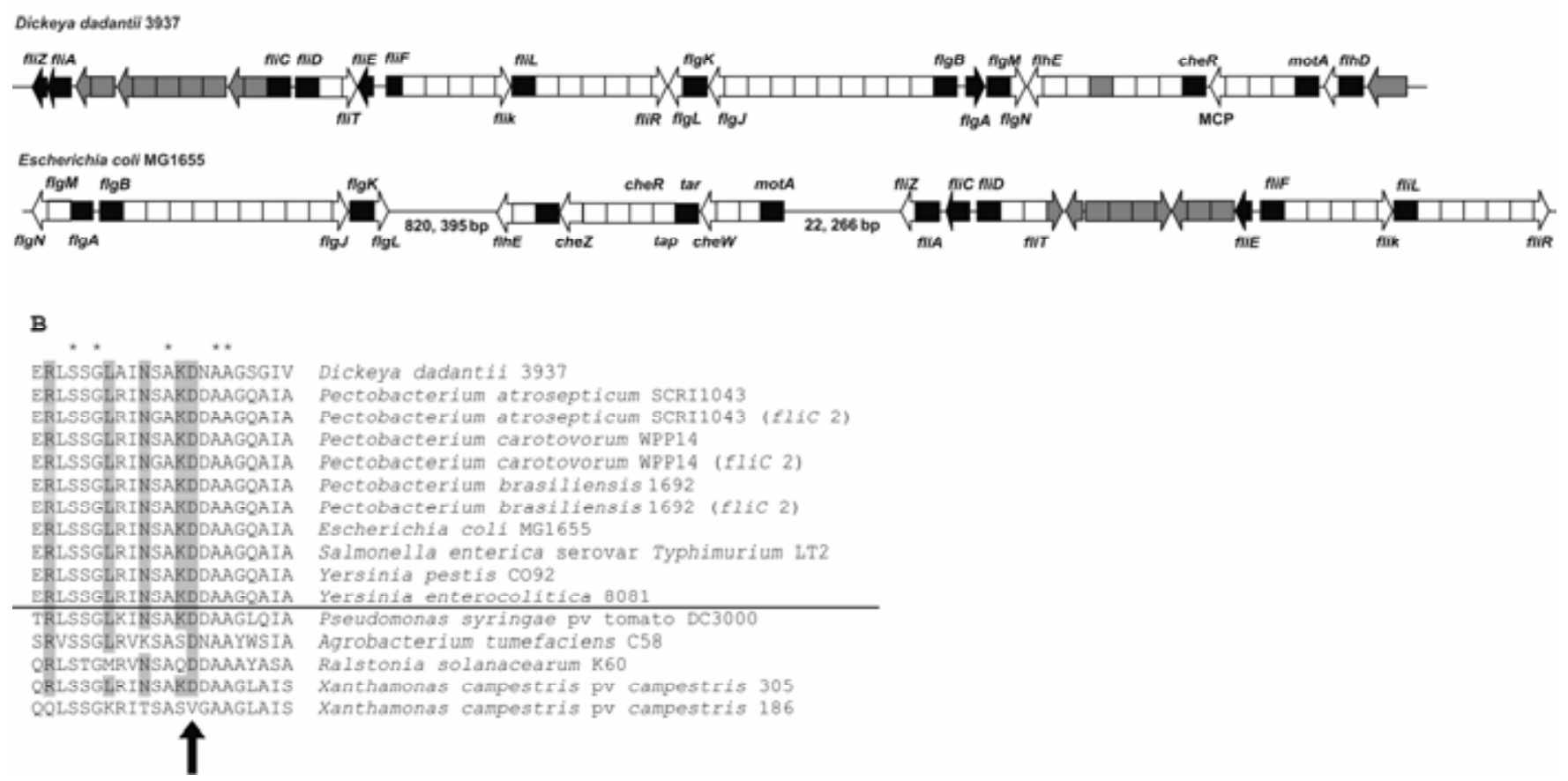

Fig. 1. Organization of flagellar genes and flg22 regions of flagellin from Enterobacteriaceae pathogens. Sequences were retrieved from the National Center for Biotechnology Information and ASAP (Glasner et al. 2003, 2006). A, Flagella genes are organized into two distinct operon structures. Dickeya dadantii and Escherichia coli are pictured as representatives. Genes are indicated by blocks and arrowheads. The start of each gene cluster is indicated with a black rectangle and arrowheads indicate direction of gene clusters. Genes are labeled at the end of each operon. Genes shaded gray are hypothetical or unknown function. Group 1 has three separate gene clusters on the chromosome while group 2 genes are in one large cluster. B, The flg 22 sequences were identified and aligned manually. Stars indicate conserved amino acids. Enterobacteriaceae species are separated from non-Enterobacteriaceae species by a line. Sun and associates (2006) determined Xanthomonas campestris pv. campestris polymorphisms between elicitors and nonelicitors of plant defense (shaded) and the arrow indicates the critical amino acid for recognition of flg22 by Arabidopsis thaliana. 
in TSB at room temperature and $28^{\circ} \mathrm{C}$ but not at $36^{\circ} \mathrm{C}$. In contrast, $D$. dadantii swarmed in $\mathrm{SM}$ at temperatures up to $36^{\circ} \mathrm{C}$. Surprisingly, although $D$. dadantii 3937 grew in LBA at $39^{\circ} \mathrm{C}$ it was unable to grow in TSA or SM at $39^{\circ} \mathrm{C}$; thus, no swarming was observed.

\section{Flagellar genes are required for pellicle formation.}

D. dadantii forms two chemically and genetically distinct types of biofilm in culture: a biofilm ring at the air-liquid-solid surface junction and a pellicle at the air-liquid interface (Yap et al. 2005). The T3SS is required for pellicle formation but the role of motility has not been examined. We used allelicexchange mutagenesis to delete the flagellar sigma factor fliA from $D$. dadantii.

As expected, the fliA mutant was not motile (Fig. 3). The biofilm ring that formed in SOBG cultures at the liquid-airsolid surface interface with the fliA mutant was only weakly attached to the glass surface, in contrast to biofilm rings that form with T3SS mutants, which are firmly attached to the surface (Yap et al. 2005). Although small aggregates formed at the air-liquid-surface interface, the fliA mutant was unable to grow outward from these aggregates; therefore, no pellicles formed, in contrast to wild-type cultures. $D$. dadantii swims but does not swarm in SOBG, and does form biofilms in SOBG; therefore, swarming motility is not likely to be important for biofilm formation in this medium.

Motility, but not biofilm formation, could be restored by expression of fliA from pGEM-T Easy in the fliA mutant (not shown). We hypothesized that downregulation of flagella genes is required for biofilm formation. Therefore, fliA, under the control of its native promoter, was inserted into the chromosome between lacY and prt in the fliA mutant. With this strategy, we successfully restored biofilm formation and motility to the fliA mutant (Fig. 3).

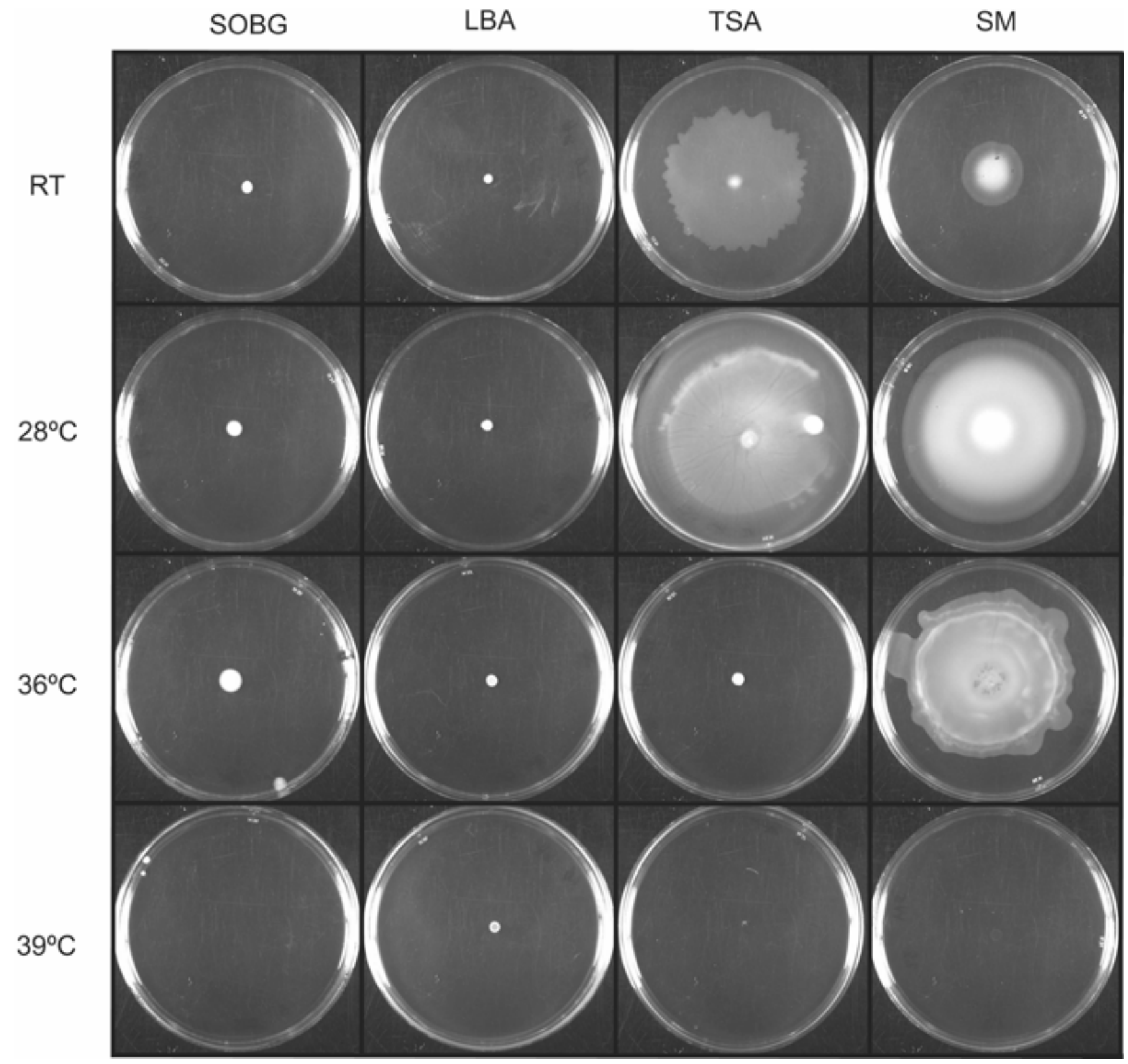

Fig. 2. Effect of temperature and medium on motility. A wild-type Dickeya dadantii cell suspension $\left(2 \mu 1,1 \times 10^{8} \mathrm{CFU} / \mathrm{ml}\right)$ was spotted onto tryptic soy agar (TSA), Luria-Bertani agar (LBA), salt-optimized broth plus 2\% glycerol (SOBG), and swarming medium (SM) containing 0.5\% agar. The plates were incubated at four different temperatures (room temperature (RT), approximately $25^{\circ} \mathrm{C}$, plus 28,36 , and $39^{\circ} \mathrm{C}$ ) and examined the next day to determine motility of D. dadantii. Swarming occurred only on some media and only at lower temperatures. Growth at $39^{\circ} \mathrm{C}$ was observed only on LBA. 


\section{D. dadantii fliA contributes}

\section{to bacterial attachment to plant tissue.}

Because FliA was required for pellicle formation, we hypothesized that this gene was also important for attachment to plant tissues. In three independent experiments, the fliA mutant was significantly reduced in attachment compared with the wild type (Table 1 , two-tailed $t$ test, $P<0.001$ ). In all three experiments, when the fliA mutation was complemented by expression of fliA from the chromosome, bacterial attachment was restored to the wild-type level (Table 1, two-tailed $t$ test, $P>0.09$ ).

\section{The D. dadantii fliA mutant is reduced}

in symptom development.

When infiltrated into Nicotiana benthamiana leaves, D. dadantii 3937 wild-type cells first cause a leaf curl and plant stunting, followed by maceration of the infiltrated region in the inoculated leaf, and sometimes proceeding to maceration of the entire inoculated leaf or the entire plant (Fig. 4). In our assay, over half of the plants inoculated (29 of 40) by infiltrating one leaf with $10^{6} \mathrm{CFU} / \mathrm{ml}$ of wild-type $D$. dadantii cells developed systemic maceration symptoms (Figs. 4 and 5). We found that the fliA mutant typically caused dry necrotic symptoms only in the region where it was inoculated into $N$. benthamiana leaves. Of the 40 plants inoculated with the fliA mutant, 3 developed systemic symptoms, with maceration extending down the leaf petiole and, in two cases, into other leaves on the plant. Thus, the fliA mutant was capable of causing systemic symptoms but at a much lower incidence than occurs with the wild type. Like wild-type $D$. dadantii, the complemented fliA mutant also caused a range of symptoms on $N$. benthamiana

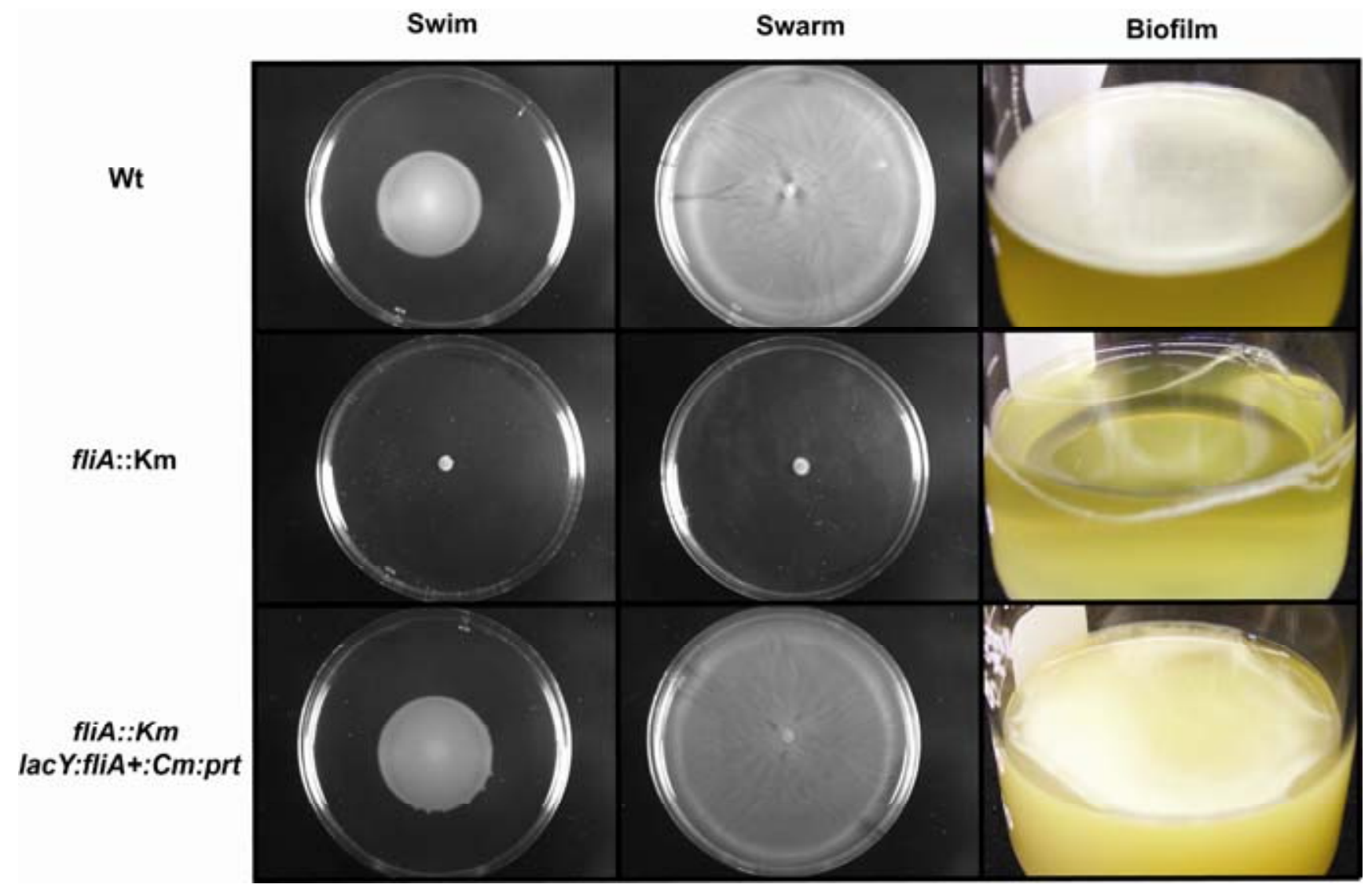

Fig. 3. Motility and biofilm formation of Dickeya dadantii. Tryptic soy agar swim and swarm plates were photographed after $24 \mathrm{~h}$ of incubation at $28^{\circ} \mathrm{C}$. Biofilm formation is demonstrated in column $3 ; \mathrm{Wt}=$ wild type. The fliA mutant was no longer motile and unable to make a pellicle or a complete biofilm ring. The chromosomal complementing clone restored these phenotypes in the fliA mutant.

Table 1. Mean $\log _{10}$ and standard error of the mean (SEM) of Dickeya dadantii 3937 cells attached to alfalfa sprouts after a 4-h incubation

\begin{tabular}{|c|c|c|c|c|}
\hline Strain, experiment ${ }^{\mathrm{y}}$ & Mean & SEM & Significantly different ${ }^{\mathrm{z}}$ & $P$ value \\
\hline \multicolumn{5}{|l|}{3937} \\
\hline 1 & 1.3 & \pm 0.08 & $\ldots$ & $\ldots$ \\
\hline 2 & 2.2 & \pm 0.28 & $\ldots$ & $\ldots$ \\
\hline 3 & 2.3 & \pm 0.08 & $\ldots$ & $\ldots$ \\
\hline \multicolumn{5}{|l|}{3937 fliA:: Km } \\
\hline 1 & 0.22 & \pm 0.10 & Yes & 0.0001 \\
\hline 2 & 0.61 & \pm 0.24 & Yes & 0.0007 \\
\hline 3 & 0.72 & \pm 0.25 & Yes & 0.0001 \\
\hline \multicolumn{5}{|c|}{3937 fliA::Km lacY:fliA ${ }^{+}:$Cm:prt } \\
\hline 1 & 1.4 & \pm 0.07 & No & 0.0983 \\
\hline 2 & 1.8 & \pm 0.25 & No & 0.3179 \\
\hline 3 & 2.4 & \pm 0.07 & No & 0.0983 \\
\hline
\end{tabular}

${ }^{\mathrm{y}}$ For experiments 1 and $3, n=10$; for experiment $2, n=9$.

${ }^{\mathrm{z}}$ Means significantly different from the wild type at $P=0.05$ as determined by two-tailed $t$ test. 
plants, with systemic spread into the petiole or other leaves observed in 32 of 40 plants.

The reduced virulence of the $D$. dadantii fliA mutant on its host was not explained simply by a reduction in growth. The mutant, the complemented mutant, and the wild-type strains were inoculated at $4.5 \mathrm{log} \mathrm{CFU} / \mathrm{g}$ of leaf tissue and all grew to an average of $7.5 \log \mathrm{CFU} / \mathrm{g}$ of leaf tissue in the inoculated leaves over the course of 3 days. No statistically significant difference in bacterial growth could be detected at days 1,2 , or 3 after inoculation as determined by one-way analysis of variance (data not shown). Therefore, disease symptoms and bacterial growth in leaves were not correlated.

\section{FliA regulates Pel production in $D$. dadantii.}

The lack of maceration symptoms without a reduction of in planta growth caused by mutation of fliA led us to the hypothesis that the decrease in symptom development was due in part to an alteration in expression of plant cell-wall-degrading enzymes. Supernatants from wild-type and fliA mutant cultures were assayed for altered levels of Pel, cellulase, and protease activity using plate activity assays. $D$. dadantii flagella mutants were not reduced in cellulase or protease activity but there was a reduction in Pel production (Fig. 6). Strains with mutations in pecS and pecT, which are known Pel regulators, were used as controls.

To quantify the effect of FliA on Pel activity, we used a spectrophotometric assay to measure Pel activity in culture supernatants of wild-type, fliA mutant, and complemented mutant culture supernatants (Collmer et al. 1988). The fliA mutant was decreased by approximately $40 \%$ in Pel activity compared with the wild type (Table 2). Expression of fliA from the chromosome restored Pel activity to levels slightly above the wild type. A pecS mutant was used as a control and mutation of this negative regulator and, as expected, resulted in production of approximately twice as much Pel activity as the wild type (Reverchon et al. 1994).

$D$. dadantii produces numerous Pels. The reduction in Pel activity could be explained by a large reduction in transcription of one or a few pel genes or a minor reduction in transcription of several pel genes in the fliA mutant. A transcriptional effect of fliA on the type II secretion system (T2SS) is unlikely because we saw no effect on cellulase activity and cellulase, like the Pels, is secreted via the T2SS. We used realtime quantitative reverse-transcriptase polymerase chain reac-

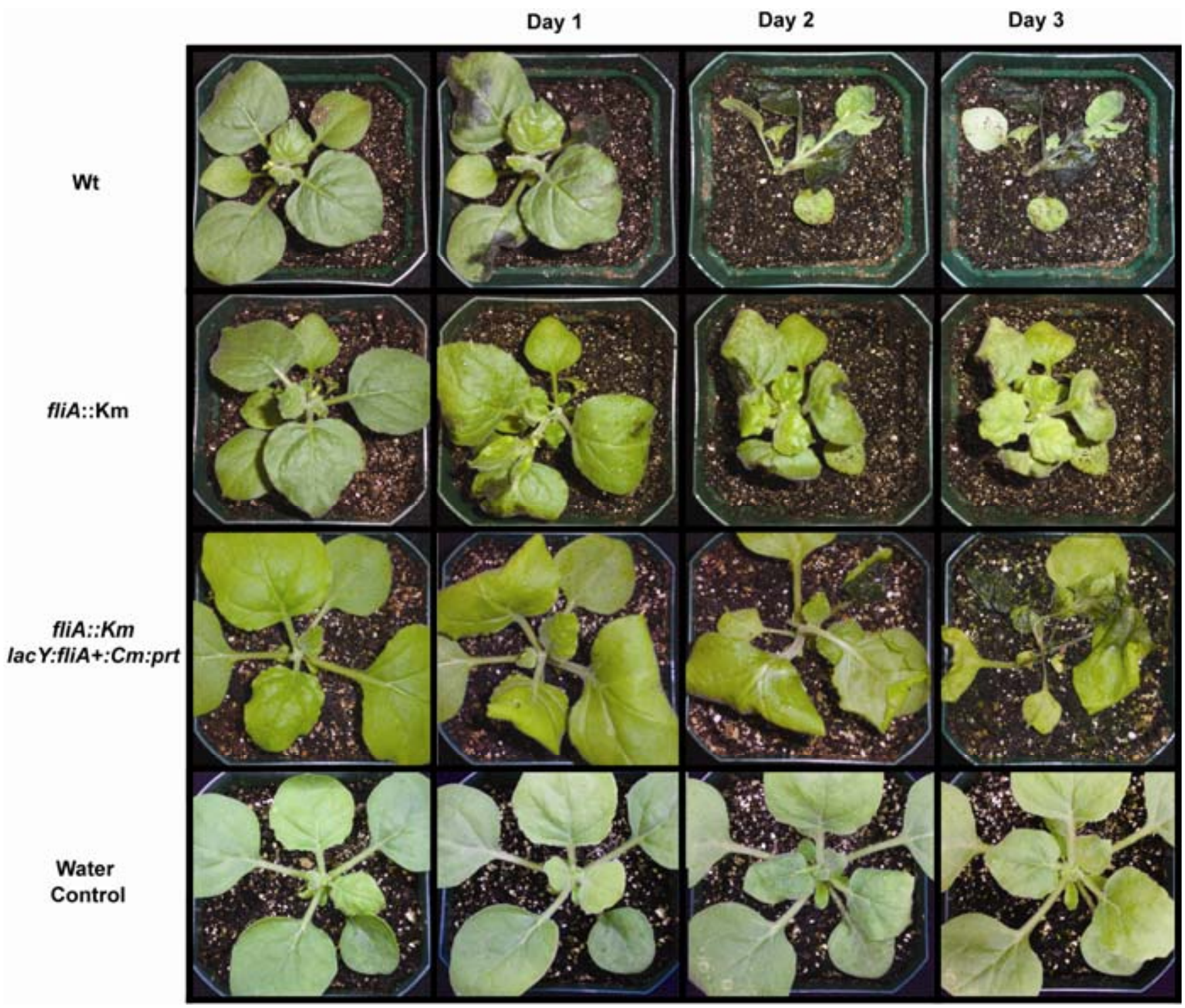

Fig. 4. Time course of symptom development with the wild-type (Wt) and fliA mutant inoculated into Nicotiana benthamiana plants. Plants were infiltrated with Dickeya dadantii at $10^{6} \mathrm{CFU} / \mathrm{ml}$, placed in plastic bags to maintain high relative humidity, and then photographed daily. Plants inoculated with Wt exhibit typical soft-rot symptoms whereas flagella mutant symptoms are less severe. 
tion (qRT-PCR) to determine whether mutation of fliA caused a reduction in mRNA accumulation of any of the pel genes. Compared with wild-type $D$. dadantii, we saw no reduction in mRNA levels for any of the 11 Pel genes examined (Table 3 ). These genes included $D$. dadantii homologs of pelA, pelB, pelC, pelD, pelE, pelI, pell, pelW, pelX, pelZ, and ABF-0019391. Rather, we observed a significant increase in mRNA levels of the periplasmic exo-Pel pelX (Shevchik et al. 1999) (2.2-fold, $P<0.0001$ ), the Pel homolog ABF-0019391 (3.2-fold, $P=$ 0.0071 ), and a gene encoding a T2SS substrate of unknown function, $a v r L$ (Kazemi-Pour et al. 2004) (1.9-fold, $P=0.0017$ ).

Some members of this set of transcripts demonstrated unusually high sample-to-sample variability, making the statistical confirmation of mean differences very difficult (Table 3 ). For example, the mean relative expression ratio (RER) of pelA and pel $W$ exceeded twofold but the high standard error of the mean (SEM) prevented establishing this difference as significant by two-tailed $t$ test. This is in contrast to transcripts such as pecT, pelZ, and pelE that exhibited very low SEM between the same RNA samples.

\section{DISCUSSION}

We found that $D$. dadantii can both swim and swarm in culture media and that swarming is affected by both media and temperature. $D$. dadantii FliA, which encodes the sigma factor that activates class III flagella genes, also contributes to pellicle formation, adherence to plant tissue, symptom development, and Pel activity. Thus, FliA is a positive regulator of multiple traits associated with virulence. Curiously, although disease symptoms and Pel activity were significantly reduced with the fliA mutant, both the wild-type and mutant strains grew to equal levels in inoculated leaves. Therefore, leaf symptoms caused by $D$. dadantii are not correlated with bacterial growth in this assay.
In $D$. dadantii and other bacterial species, multiple genes contribute to both biofilm formation and virulence (Koutsoudis et al. 2006; O'Toole and Kolter 1998; Yap et al. 2005). The elimination of pellicle formation in the fliA mutant might be

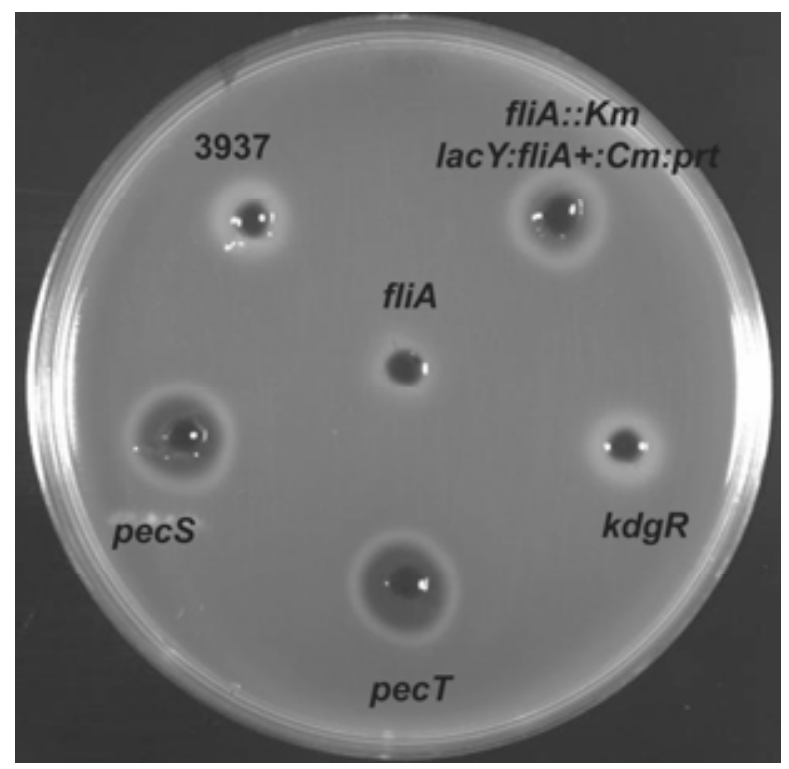

Fig. 6. Phenotypic characterization of an fliA mutant using a pectate lyase plate activity assay. Strains were grown overnight in polypectate enrichment medium at $30^{\circ} \mathrm{C}$ with shaking. Culture supernatants were added to wells in the assay medium, and plates were incubated at $28^{\circ} \mathrm{C}$ and developed at $24 \mathrm{~h}$. Pectate lyase activity is evident as a white halo or cleared zone surrounding the well. The gene mutated in each strain used is indicated by each well. The assay was repeated three times and representative results are shown.

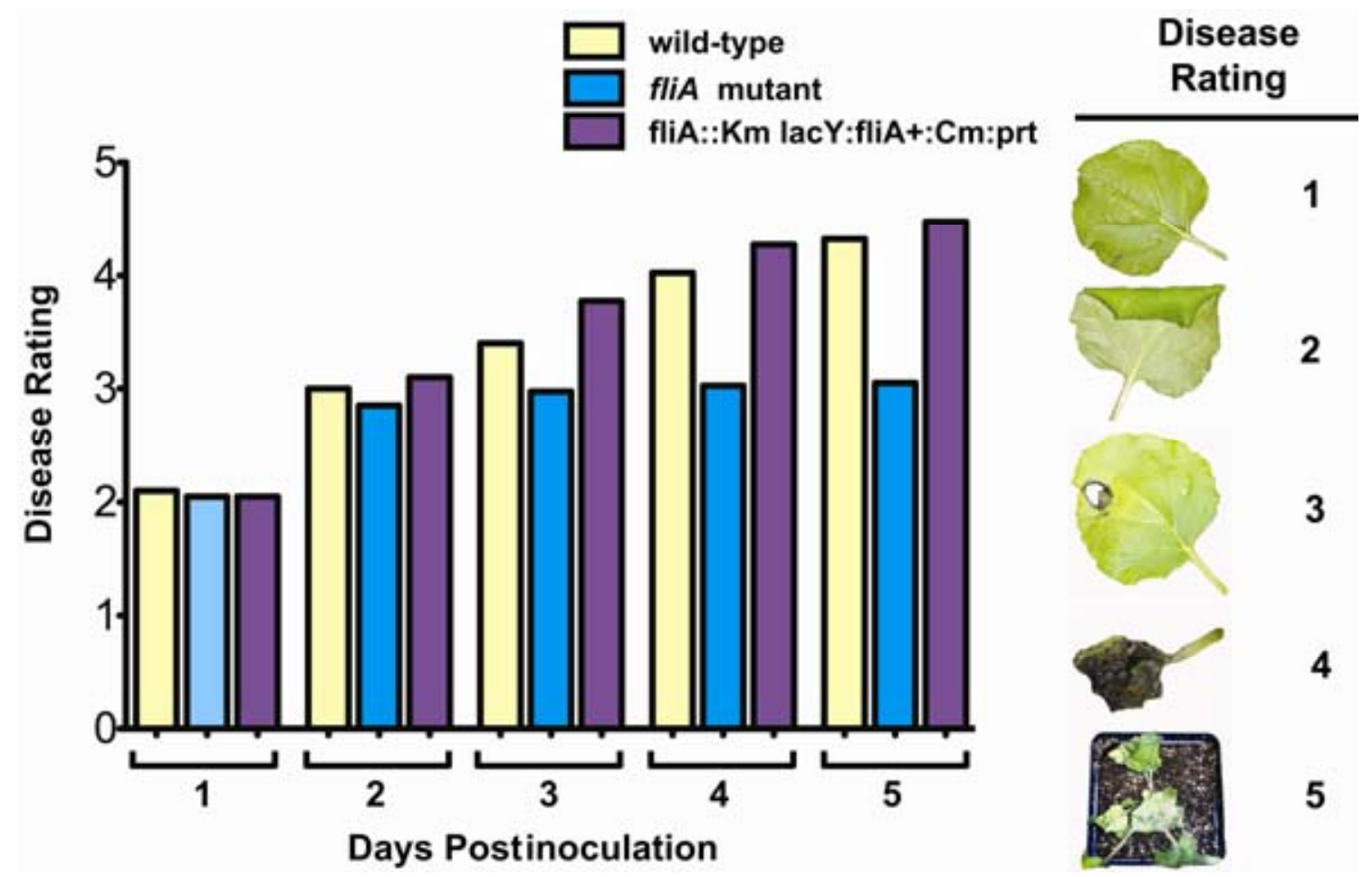

Fig. 5. Disease rating of Nicotiana benthamiana after infiltration with the wild type and the fliA mutant. A single leaf was infiltrated with $10^{6} \mathrm{CFU} / \mathrm{ml}$, and the plants were placed in plastic bags and evaluated daily for symptom development. Plants were rated using the following scale: $1=$ no symptoms, $2=$ leaf curl, $3=$ maceration at infection site, $4=$ maceration into petiole, and $5=$ systemic spread. Each bar indicates the mean disease rating for each day post inoculation. Over the course of 5 days, a $\chi^{2}$ analysis indicated that the fliA mutant was significantly different from the wild type $(P<0.0001)$ whereas the complementing clone was not significantly different from the wild type $(P=0.0635)$. 
due to the requirement for motility in order to reach the airliquid interface. However, our data show that the fliA mutant formed aggregates on the sides of test tubes at the air-liquidsurface interface. Thus, bacteria were present at the air-liquid interface and outward growth to form a pellicle should be possible if reaching the culture surface was all that was required. The lack of a bacterial aggregation demonstrates that FliAregulated genes are required for wild-type bacterial aggregation. Flagella can function as adhesins (Arora et al. 1998); however, because FliA has also been shown to regulate pili production in E. coli (Claret et al. 2007), the lack of aggregation observed in the $D$. dadantii fliA mutant is not necessarily due to the lack of flagella in the fliA mutant. .

Several transcriptional regulators have been identified as contributing to both bacterial attachment to plants and biofilm formation in culture (Barak et al. 2005). We used alfalfa sprouts to test bacterial adherence to plants because they can be handled whole, lending themselves well to in situ experiments. Damaged plant tissue is sticky and bacteria that normally do not adhere to intact plant tissue will adhere to wounded tissue; therefore, leaf disks were not used (Wachtel and Charkowski 2002). Also, Dickeya spp. cause bacterial sprout rot of alfalfa, making this a relevant model (Moline and Kulik 1997; Pierce and McCain 1985). Mutation of fliA reduced, but did not eliminate, the ability of $D$. dadantii to adhere to plant tissue; thus, FliA-regulated genes contribute to adherence of bacterial cells to each other during both biofilm formation and adherence to plant tissue. As with biofilm formation, the contribution of $D$. dadantii FliAregulated genes to bacterial adhesion to plant tissue is probably due to a bacterial adhesin and not due solely to bacterial motility because the sprouts were agitated in a suspension of bacteria on a rotating incubator during the adhesion assay. It was not surprising that the bacterial adhesion to plant tissue was only partially reduced in the fliA mutant. In the related species, $S$. enterica, multiple polymers contribute to bacterial adherence to plant tissue and elimination of any single polymer results in only a partial reduction in bacterial adherence to plant tissue (Barak et al. 2007).

We used the model plant $N$. benthamiana to evaluate the role of FliA in $D$. dadantii pathogenicity. When inoculated into $N$. benthamiana leaves, $D$. dadantii multiplies by up to three $\log$ orders in the inoculated leaves, which is comparable to the level of multiplication observed in the plant host from which this strain was initially isolated, Saintpaulia (African violet) leaves (Okinaka et al. 2002; Yang et al. 2008). The symptoms caused by $D$. dadantii on $N$. benthamiana progress in a predictable manner. The bacteria first cause the inoculated leaf to curl, then the inoculated leaf decays, and finally the decay spreads down the leaf petiole and to the rest of the plant. Leaf curl and dwarfing symptoms have not been reported previously with $D$. dadantii, perhaps because most virulence assays have been performed with petioles of detached witloof chicory leaves, potato tubers, or fleshy Saintpaulia leaves. Although the fliA mutant grew as well as the wild type in inoculated leaves, it failed to cause systemic maceration symptoms. Bac-

Table 2. Pectate lyase activity of Dickeya dadantii mutant strains compared with the wild type

\begin{tabular}{lc}
\hline Strain & $\begin{array}{c}\text { Pectate lyase activity } \\
(\mu \mathbf{m o l} / \mathbf{m i n})^{\mathbf{z}}\end{array}$ \\
\hline 3937 & $0.303 \pm 0.055 \mathrm{~A}$ \\
WPP 381, 3937 fliA::Km & $0.177 \pm 0.019 \mathrm{~B}$ \\
WPP382, 3937 fliA::Km lacY:fliA ${ }^{+}:$Cm:prt & $0.405 \pm 0.036 \mathrm{C}$ \\
3937 pecS::MudIIPR13 & $0.615 \pm 0.088 \mathrm{D}$ \\
\hline
\end{tabular}

${ }^{\mathrm{z}}$ Values followed by different letters are significantly different at $P=0.05$ according to Tukey's highly significant difference. terial growth without symptom development has been seen with other plant pathogens as well (Willis et al. 1990). However, the fliA mutant did cause extensive leaf curling and plant dwarfing. D. dadantii produces auxin (Yang et al. 2007) and we have recently found that auxin production is required for the leaf curl and dwarfing symptoms to develop (unpublished observations).

The fliA mutant grew as well as the wild type in inoculated leaves and caused systemic dwarfing and leaf curl symptoms but did not macerate the inoculated plants; therefore, we hypothesized that mutation of fliA affected plant cell-wall-degrading enzyme production. We found that Pel but not cellulase or protease activity was reduced in the fliA mutant. The magnitude of the effect of FliA on Pel activity is similar to that of PecS, except in the opposite direction. Mutation of FliA results in slightly less than a onefold decrease whereas mutation of PecS causes a onefold increase in Pel activity compared with wild-type cultures. Because the fliA mutant has lower Pel activity, we hypothesized that FliA is likely to regulate one or more of the 11 Pel genes encoded by $D$. dadantii either directly through activation of transcription or indirectly by derepression of pecT or another regulator. FliA is not likely to act through the Pel regulators KdgR, CRP, or PecS because, unlike PecT, these regulators also control cellulase activity and cellulase activity was not affected in the fliA mutant. FliA is also not likely to act through the acyl-homoserine lactone (AHL) quorumsensing system because AHL-based quorum sensing plays only a minor role in regulating plant cell-wall-degrading enzymes in D. dadantii (Nasser et al. 1998). E. coli and S. enterica FliA binds to TAAAGTTT-N 11 -GCCGATAA (Ide et al. 1999) and a similar sequence is found upstream of some $D$. dadantii flagellar operons. No putative FliA binding sites were found in the pecT or Pel gene promoters; thus, the $D$. dadantii genome sequence revealed no clues for the mechanism by which FliA affects Pel production.

The reduction in Pel activity observed could be due to a large reduction in expression of 1 or 2 of the 11 Pel genes, but

Table 3. Quantification of transcripts in the wild type and fliA mutants

\begin{tabular}{lccc}
\hline $\begin{array}{l}\text { Characterization, } \\
\text { name }^{\mathbf{v}}\end{array}$ & $\begin{array}{c}\text { Target transcript } \\
\text { RER }^{\mathbf{w}}\end{array}$ & SEM $^{\mathbf{x}}$ & $\boldsymbol{P}$ value $^{\mathbf{y}}$ \\
\hline $\begin{array}{l}\text { Negative regulator } \\
\text { pecT }\end{array}$ & 0.90 & \pm 0.06 & 0.7542 \\
$\begin{array}{l}\text { Major pectate lyases } \\
\text { pelA }\end{array}$ & 2.51 & \pm 1.08 & 0.2774 \\
pelE & 0.92 & \pm 0.05 & 0.4384 \\
pelD & 2.07 & \pm 0.60 & 0.1970 \\
pelB & 1.12 & \pm 0.21 & 0.6513 \\
pelC & 1.18 & \pm 0.07 & 0.6210 \\
Minor pectate lyases & & & \\
pelZ & 0.81 & \pm 0.05 & 0.1092 \\
pelW & 2.78 & \pm 0.64 & 0.0531 \\
pelL & 1.39 & \pm 0.33 & 0.4291 \\
pelI & 1.73 & \pm 0.42 & 0.1366 \\
pelX & 2.24 & \pm 0.11 & $<0.0001^{\mathrm{z}}$ \\
Predicted pectate lyase & & & \\
ABF-0019391 & 3.22 & \pm 0.65 & $0.0071^{\mathrm{z}}$ \\
Unknown function & & & \\
avrL & 1.89 & \pm 0.12 & $0.0017^{\mathrm{z}}$ \\
\hline
\end{tabular}

${ }^{\mathrm{v}}$ Gene name or ASAP identification number.

${ }^{\mathrm{w}} \mathrm{RER}=$ relative expression ratio of the target transcript in the fliA mutant using the target transcript abundance in wilt-type Dickeya dadantii as a calibrator.

${ }^{x}$ Standard error of the mean.

${ }^{y}$ Determine by two-tailed $t$ test with a 95\% confidence interval using Prism 5.0a software (GraphPad Software, Inc.).

${ }^{\mathrm{z}} \mathrm{A} P$ value $<0.05$ indicates that the mean RER of the target transcript in the fliA mutant was significantly different from the target gene mean RER in the wild type. 
we found no significant reduction in Pel mRNA accumulation in the fliA mutant, disproving this hypothesis. If the reduction in enzyme activity observed is due to a relatively small reduction in mRNA levels of multiple Pel genes, it may not be possible to detect by real-time qRT-PCR. We observed slight (less than onefold) reduction in Pel activity and a concurrent reduction in mRNA levels is a difference of less than one qRT-PCR cycle.

Surprisingly, two Pel homologs, pelX and ABF-0019391, and a gene of unknown function, $a v r L$, were upregulated in the fliA mutant relative to the wild type. PelX differs from the other Pels in that it is a periplasmic exo-Pel that is not solely dependent on calcium ions for activity and is not regulated by PecT (Shevchik et al. 1999). PelX is not secreted and has low enzymatic activity compared with many of the other Pels; therefore, it is unlikely that PelX contributed to the enzyme activity measured. The Pel homolog ABF-0019391 is most similar to PelL and has orthologs in all three sequenced Pectobacterium genomes; however, there is no biochemical data available on the enzyme encoded by this gene. AvrL is a T2SSsecreted protein homologous to a Xanthomonas protein, AvrXca, a protein that confers an avirulence phenotype when Xanthomonas campestris is inoculated onto Arabidopsis (Kazemi-Pour et al. 2004; Parker et al. 1993).

Several studies have shown evidence for the disparity between mRNA and protein abundance but few have looked at relative expression levels of mRNA and the corresponding enzyme activities. In cases where both are examined, unpredictable results sometimes have been obtained (Anderson and Seilhamer 1997; Glanemann et al. 2003; Gygi et al. 1999). For example, in E. coli LF82, FliA regulates type 1 pili biosynthesis via GGDEF and EAL domain proteins in a complex manner that cannot be simply related to the effect of FliA on transcription of these GGDEF and EAL regulatory proteins (Claret et al. 2007).

The flagellar operons of the soft rot pathogens Dickeya and Pectobacterium spp. are similar in organization and the soft rot bacterial flagellins are similar in that they all include a flg22 sequence likely to activate defenses in at least some plant species via the resistance protein FLS2 (Chinchilla et al. 2006; Felix et al. 1999; Gomez-Gomez and Boller 2002; Sun et al. 2006). Consistent with this, a, FLS2-like response to Dickeya and Pectobacterium crude extracts was reported in tomato by Felix and associates (1999). Because this motif is conserved in both soft rot genera as well as in closely related human pathogens such as $S$. enterica and $E$. coli, defense responses against flagellin apparently do not provide enough pressure to select for flagella that lack the eliciting amino acids in the flg22 sequence in the soft rot enterobacteria.

FliA contributes to pellicle formation, aggregation, virulence, and enzyme production and regulates mRNA accumulation of two Pel homologs and avrL, suggesting that there is substantial interplay between known $D$. dadantii virulence genes and those required for motility. Our current knowledge only covers small fragments of how these pathways overlap. Unraveling the multiple mechanisms and signals used to coregulate motility and virulence proteins may lead to new control methods for plant-pathogenic bacteria.

\section{MATERIALS AND METHODS}

\section{Bacterial strains and growth conditions.}

Wild-type $D$. dadantii and derivatives were grown in LuriaBertani (LB) medium or polypectate enrichment medium (PEM) (sodium polypectate at $1.5 \mathrm{~g} /$ liter, $\left(\mathrm{NH}_{4}\right)_{2} \mathrm{SO}_{4}$ at 0.13 $\mathrm{g} / \mathrm{liter}, \mathrm{K}_{2} \mathrm{HPO}_{4}$ at $0.17 \mathrm{~g} / \mathrm{liter}$, and $\mathrm{MgSO}_{4} \cdot 7 \mathrm{H}_{2} \mathrm{O}$ at 0.06 $\mathrm{g} /$ liter) (De Boer and Kelman 2001) at $37^{\circ} \mathrm{C}$ for DNA isolation and mutagenesis. The growth medium used to induce biofilm formation, SOBG, consisted of salt-optimized broth plus $2 \%$ glycerol (20 g of tryptone, $5 \mathrm{~g}$ of yeast extract, $0.5 \mathrm{~g}$ of $\mathrm{NaCl}$, $2.4 \mathrm{~g}$ of $\mathrm{MgSO}_{4}, 0.186 \mathrm{~g}$ of $\mathrm{KCl}$, and $50 \mathrm{ml}$ of $40 \%$ glycerol per liter) (Yap et al. 2005). For pellicle assays, bacterial cultures were suspended in SOBG to approximately $10^{6} \mathrm{CFU} / \mathrm{ml}$ and incubated at $25^{\circ} \mathrm{C}$ in stationary 20 -mm glass tubes or 100 $\mathrm{ml}$ beakers for at least 3 days. For swarm and swim motility assays, $2 \mu \mathrm{l}$ of an overnight culture was spotted in the middle of a swim plate $(0.3 \%$ [wt/vol] agar) or a swarm plate $(0.5 \%$ [wt/vol] agar) and allowed to dry at room temperature. Media used for motility assays included LBA, SOBG, TSA (pancreatic digest of casein at $17 \mathrm{~g} / \mathrm{liter}$, enzymatic digest of soybean meal at $3 \mathrm{~g} / \mathrm{liter}$, dextrose at $2.5 \mathrm{~g} /$ liter, sodium chloride at 5 $\mathrm{g} /$ liter, and dipotassium phosphate at $2.5 \mathrm{~g} / \mathrm{liter}$ ), and SM (beef extract at $3 \mathrm{~g} /$ liter, peptone at $5 \mathrm{~g} / \mathrm{liter}$, and $25 \mathrm{ml}$ of $20 \%$ glucose). All plates were incubated at room temperature, 28, 36, and $39^{\circ} \mathrm{C}$ for 12 to $16 \mathrm{~h}$.

Enzyme plate assays of enzymatic activity were modified from Chatterjee and associates (1995). Briefly, the media compositions were as follows: $\mathrm{Pel}$ assay medium $=1 \%$ polygalacturonic acid (PGA), $1 \%$ yeast extract, $0.38 \mathrm{mM} \mathrm{CaCl}_{2}$, and 100 $\mathrm{mM}$ Tris- $\mathrm{HCl}, 0.8 \%$ agar, $\mathrm{pH} 8.5$; cellulase $(\mathrm{Cel})$ assay medium $=0.1 \%$ carboxymethyl cellulose and $25 \mathrm{mM}$ sodium phosphate, $0.8 \%$ agar, $\mathrm{pH} 7.0$; and protease (Prt) assay me-

Table 4. Strains and plasmids used in this study

\begin{tabular}{|c|c|c|}
\hline Strains, plasmids & Relevant characteristics $^{\mathrm{z}}$ & Source \\
\hline \multicolumn{3}{|l|}{ Escherichia coli } \\
\hline DH5 $\alpha$ & 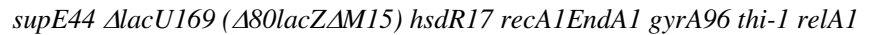 & $\ldots$ \\
\hline \multicolumn{3}{|l|}{ Dickeya dadantii } \\
\hline 3937 & Wild-type, Saintpaulia ionantha (African violet) isolate & Lemattre and Narcy 1972 \\
\hline$k d g R:: \operatorname{miniTn} 5-\mathrm{Sm}$ & $\operatorname{lmrT}($ con) lacZ2 kdgR::miniTn5-Sm & Nasser et al. 2005 \\
\hline pecS::MudIIPRI3 & $\operatorname{lmrT}($ con) lacZ2 pecS::MudIIPRI3 & Reverchon et al. 1994 \\
\hline pecT::uidA $\mathrm{Cm}$ & $\operatorname{lmr} T($ con) lacZ2 pecT::uidA $C m$ & Surgey et al. 1996 \\
\hline Nx3937 & $3937 \mathrm{Nx}^{\mathrm{r}}$ derivative & Yap et al. 2008 \\
\hline WPP381 & fliA::Km & This work \\
\hline WPP382 & Chromosomal insertion lacY-fliA-Cm-prt & This work \\
\hline \multicolumn{3}{|l|}{ Plasmids } \\
\hline pGEM-T Easy & $\mathrm{Ap}^{\mathrm{r}}$, lac $Z^{\prime}$, cloning vector & Promega Corp. \\
\hline pKD4 & $\mathrm{Km}^{\mathrm{r}}$, template plasmid carrying kan cassette & Datsenko and Wanner 2000 \\
\hline pKD3 & $\mathrm{Cm}^{\mathrm{r}}$, template plasmid carrying cat cassette & Datsenko and Wanner 2000 \\
\hline pTCLS $_{\mathrm{AD}}$ & $\mathrm{Ap}^{\mathrm{r}}, 2.8-\mathrm{kb}$ lacY-prt region in pGEM-T Easy & Yap et al. 2008 \\
\hline pTfliA::Km & $\mathrm{Ap}^{\mathrm{r}} \mathrm{Km}^{\mathrm{r}}, 3.2-\mathrm{kb}$ fragment containing fliA::Km in pGEM-T Easy & This work \\
\hline pTfliAc & $\mathrm{Ap}^{\mathrm{r}}, 2-\mathrm{kb}$ fliA in pGEM-T Easy & This work \\
\hline pCLSfliA-Cm & $\mathrm{Ap}^{\mathrm{r}} \mathrm{Cm}^{\mathrm{r}}$, 4.1-kb lacY-fliA-Cm-prt region in pGEM-T Easy & This work \\
\hline
\end{tabular}

${ }^{\mathrm{z}} \mathrm{Nx}^{\mathrm{r}}, \mathrm{Ap}^{\mathrm{r}}, \mathrm{Km}^{\mathrm{r}}$, and $\mathrm{Cm}^{\mathrm{r}}=$ resistant to nalidixic acid, ampicillin, kanamycin, and chloramphenicol, respectively. 
dium $=3 \%$ gelatin, $0.8 \%$ agar, and $0.4 \%$ nutrient broth. The best results with the Pel medium were obtained using polygalacturonic acid from ICN Biomedicals Inc. (Aurora, OH, U.S.A.). Each petri plate (100-mm diameter) contained $15 \mathrm{ml}$ of assay medium. Wells were made with a no. 2 cork borer and the bottom of the wells were sealed with molten agarose $(0.8 \%$ [wt/vol] in water). Overnight culture or culture supernatant (10 $\mu \mathrm{l})$ was applied to the wells and the assay plates were incubated at $28^{\circ} \mathrm{C}$. Cultures were treated with tetracycline to inactivate bacterial cells prior to application to enzyme assay plates. Pel plates were developed with $4 \mathrm{~N} \mathrm{HCl}$ until zones of clearing formed. Cel plates were developed with $0.1 \%$ congo red for 45 min and then washed with $1 \mathrm{M} \mathrm{NaCl}$ until zones of clearing appeared. Prt plates developed zones of clearing after incubation of 24 to $36 \mathrm{~h}$ without further treatment. Strains used in this study are described in Table 4.

\section{Mutant and plasmid construction.}

Primers were obtained from Integrated DNA Technologies, Inc. (Coralville, IA, U.S.A.). To construct plasmids for allelicexchange mutagenesis and complementation, genes were PCRamplified with the primer sets listed in Table 5. The products were cloned into pGEM-T Easy (Promega Corp., Madison, WI, U.S.A.). To disrupt fliA, a kanamycin resistance cassette was ligated into the unique restriction site $X m a I$ in pGEM-T Easy::fliA.

These plasmids were electrotransformed into $D$. dadantii strains for allelic-exchange following methods previously described (Ried and Collmer 1987). All mutations were confirmed by PCR and Southern blot analysis. fliA was inserted into the chromosome using allelic exchange mutagenesis for complementation of mutations. To construct plasmids to complement the gene mutations, the promoter and coding regions of the genes were PCR amplified. The PCR products were cloned into pGEM-T Easy and then moved into pTCLS AD $_{\text {(Yap }}$ et al. 2008). pTCLS ${ }_{\mathrm{AD}}$ includes the lacY-prt locus plus an engineered multicloning site. This plasmid was designed to insert genes into a neutral chromosomal site. These plasmids were electrotransformed into mutant strains and allelic exchange was used to move the wild-type allele onto the chromosome.

When required, antibiotics were used at the following concentrations: ampicillin (100 $\mu \mathrm{g} / \mathrm{ml})$, chloramphenicol (50 $\mu \mathrm{g} / \mathrm{ml})$, streptomycin $(50 \mu \mathrm{g} / \mathrm{ml})$, and kanamycin $(50 \mu \mathrm{g} / \mathrm{ml})$. Transformation, restriction endonuclease digestion, and other DNA techniques were performed as described (Sambrook and Russell 2001).

\section{Virulence assays.}

One-week-old $N$. benthamiana seedlings were transplanted into 4 -in. pots. Seedlings were placed in a growth chamber operating at $25^{\circ} \mathrm{C}$ with $12 \mathrm{~h}$ of continuous light per 24 -h period. Light was provided by $40-\mathrm{W}$ cool-white fluorescent bulbs at $240 \mu \mathrm{mol} / \mathrm{m} / \mathrm{s}$ of photons. Plants were watered once daily and fertilized once per week with a 50\% solution of Miracle Grow (Scotts Co., Marysville, OH, U.S.A.). Plant assays were performed essentially as described (Hirano et al. 1997). Four- to six-week-old $N$. benthamiana leaves were infiltrated with a bacterial suspension of $10^{4} \mathrm{CFU} / \mathrm{ml}$. Infected plants were placed in plastic bags and incubated in a growth chamber at $25^{\circ} \mathrm{C}$ throughout the course of the assay. At each sampling time, whole leaves were homogenized using a Polytron equipped with a model PTA 20 TS probe (Brinkmann Instruments, Westbury, NY, U.S.A.) in $20 \mathrm{ml}$ of sterile water and the suspension was dilution plated on LBA medium plus appropriate antibiotics.

To evaluate symptom progression, 6-week-old $N$. benthamiana leaves were infiltrated with a bacterial suspension of $10^{6}$ $\mathrm{CFU} / \mathrm{ml}$. One leaf was infiltrated per plant, the potting mix was saturated with water, and the plants were placed in plastic bags and then incubated in a growth chamber at $25^{\circ} \mathrm{C}$ throughout the course of the assay. Plastic bags were opened daily to evaluate disease progression and to allow for air exchange. Plants were rated using the following scale: $1=$ no symptoms, $2=$ leaf curl, $3=$ maceration at infection site, $4=$ maceration into petiole, and $5=$ systemic spread. This data was analyzed using a $\chi^{2}$ test with the general linear model (SAS version 9.1.3; SAS institute, Inc., Cary, NC, U.S.A.).

\section{Alfalfa sprout attachment assays.}

Alfalfa sprout assays were performed as described previously (Barak et al. 2005). Alfalfa seed (5 g) was surface sanitized with $50 \mathrm{ml}$ of $3 \%$ calcium hypochlorite for $20 \mathrm{~min}$ by agitation on a rotary shaker at $250 \mathrm{rpm}$. Fifty seeds were sprouted in petri plates with $20 \mathrm{ml}$ of sterile water and irrigation water was exchanged daily. Overnight bacterial cultures grown on SOBG were suspended in sterile water at a concentration of approximately $10^{4} \mathrm{CFU} / \mathrm{ml}$ for attachment assays. For attachment assays, seed were germinated in sterile water for 3 days with daily water changes. After 3 days, sprouts were transferred petri dishes (11 sprouts per dish) and incubated in bacterial suspensions for $1 \mathrm{~h}$ at room temperature with constant shaking at $75 \mathrm{rpm}$. Sprouts were rinsed three times with sterile water and $10 \mathrm{~s}$ of gentle shaking each wash, and then homogenized. The homogenate was plated and the cultures were incubated overnight at $37^{\circ} \mathrm{C}$; then, the colonies were enumerated. The experiment was repeated three times with at least nine sprouts analyzed per strain each time. Statistical analysis was performed using a two-tailed $t$ test with a 95\% confidence interval using Prism version 5.0a (GraphPad Software, Inc., La Jolla, CA, U.S.A.).

\section{Pel activity assay.}

Cultures were grown overnight in SOBG; then a $100-\mu 1$ aliquot of each culture was added to $5 \mathrm{ml}$ of PEM broth prepared with polypectate obtained from Sigma and the cultures were incubated at $30^{\circ} \mathrm{C}$ for $12 \mathrm{~h}$. Supernatant from the PEM cultures

Table 5. Oligonucleotides used in this study

\begin{tabular}{|c|c|c|c|}
\hline Primer & Sequence $\left(5^{\prime} \rightarrow 3^{\prime}\right)$ & Restriction site $^{\mathrm{z}}$ & Amplified region \\
\hline P0198 & CTGCAGGATCCGTGTAGGCTGGAGCTGCTTC & PstI, BamHI & \\
\hline P0199 & CTGCAGGATCCCATATGAATATCCTCCTTA & PstI, BamHI & $1-\mathrm{kb}$ cat or $1.6-\mathrm{kb} \mathrm{kan}$ \\
\hline P0520 & AGAATTCCCGCCAACTCCTATCTTATTG & EcoRI & \\
\hline P0519 & ATAGCTTGAATTCCTCCCAACTGAACC & EcoRI & 3.2-kb fliA spanning region \\
\hline P0520 & ACCCATATTGCGCGGATTGATGC & $\ldots$ & $\ldots$ \\
\hline P0521 & TTCTTCCTGGTTGCTTGAGGCATGAG & $\ldots$ & 1.3-kb fliA spanning region \\
\hline P0522 & AATGCGATTGCCTTGTCTAATCTGG & $\ldots$ & \\
\hline P0523 & AGGAACATCTTCATCTGATTGACG & $\ldots$ & 4.0-kb fliA spanning region \\
\hline P0409 & ATGGACATCAGCTCTGCGACC & $\ldots$ & $\ldots$ \\
\hline P0412 & TATCTGATGGGTGCTGGCAT & $\ldots$ & 2.8-kb lacY-prt \\
\hline
\end{tabular}

${ }^{\mathrm{z}}$ Restriction sites are indicated in the primer sequence by italic or bold text. 
was harvested by centrifugation and added to room-temperature Pel activity substrate $(0.1 \%$ PGA from ICN Biomedical Inc., $100 \mathrm{mM}$ Tris-HCL [pH 8.5], and $0.69 \mathrm{mM} \mathrm{CaCl}_{2}$ ). Enzyme activity was measured for 20 min using a Synergy HT Multi-Detection Microplate Reader (BIO-TEK Instruments, Inc., Winooski, VT, U.S.A.). Pel activity was defined as the conversion of $1 \mu \mathrm{mol}$ of substrate to unsaturated uronide per minute (Nagel and Anderson 1965). Treatments were assessed using the PROC GLM function, and Tukey-Kramer's honestly significant difference (HSD) was used to evaluate multiple comparisons at the treatment level. Statistical analysis was done using Statistical Analysis Software (version 9.1; SAS Inc.). Tukey's HSD was used to assess treatment differences. The experiment was repeated six times.

\section{RNA isolation.}

D. dadantii proved to be an extremely difficult organism from which to isolate intact RNA of sufficient quality for realtime qRT-PCR analysis (Jahn et al. in press). Bacteria were cultured for $12 \mathrm{~h}$; then, $1.25 \mathrm{ml}$ of ice-cold ethanol containing $5 \%$ water-saturated phenol was added to the culture. Cells were harvested by centrifugation at $6,000 \times \mathrm{g}$ at $4^{\circ} \mathrm{C}$ and then the cell pellets were flash-frozen in liquid $\mathrm{N}_{2}$. Total RNA was isolated from cell pellets using a modified hot phenol method (Jahn et al. in press). RNA was treated with $2 \mathrm{U}$ of Turbo DNA-free (Ambion, Austin, TX, U.S.A.) for $1 \mathrm{~h}$ at $37^{\circ} \mathrm{C}$ using the rigorous protocol and quantified by UV spectrophotometry (NanoDrop, Inc., Wilmington, DE, U.S.A.). RNA quality was determined with microfluidic capillary electrophoresis using Agilent 2100 Bioanalyzer (Agilent Technologies, Palo Alto, CA, U.S.A.). All RNA samples used had an RNA integrity number (RIN) value $>7.0$ because we found that RNA quality as determined by an RIN > 7.0 is essential for successful realtime qRT-PCR with $D$. dadantii total RNA (Jahn et al. in press). Residual DNA contamination was quantified using real-time PCR and primers specific for the Dickeya rplU gene (Table 6). Those RNA samples showing threshold cycle $\left(C_{t}\right)$ values $\geq 33$ cycles were deemed to be sufficiently free of DNA contamination for further study.

\section{Real-time RT-PCR primer design.}

Primers were designed based on $D$. dadantii DNA sequences obtained from ASAP (Glasner et al. 2003, 2006) that were imported into Beacon Designer software (Premier Biosoft International, Palo Alto, CA, U.S.A.); a program designed to generate primer pairs suitable for real-time PCR. The SYBR Green module with program setting "avoid template structure" was chosen to limit primer sequences to regions of little secondary template structure. Primers were obtained from IDT (Integrated DNA Technologies) and their sequences are shown in Table 6. Both reference and target primers exhibited comparable efficiencies as determined using a dilution series of target DNA. Primer efficiencies were determined from dilution curve using the formula $\mathrm{E}=10^{(-1 / \mathrm{slope})}$ (Pfaffl et al. 2004), with the slope determined by the MyiQ software (Table 6).

\section{cDNA synthesis and real-time RT-PCR.}

First-strand cDNA synthesis was performed using the iScript cDNA synthesis kit according to the manufacturer's instructions (Bio-Rad Laboratories, Hercules, CA, U.S.A.). Briefly, the reaction was performed with $1.0 \mu \mathrm{g}$ of total RNA in $15 \mu \mathrm{l}$ of RNase-free water, $4 \mu$ l of $5 \times$ iScript reaction mix with a blend of oligo dT and random hexamer primers, and $1 \mu$ of iScript reverse transcriptase. The reaction conditions were performed

Table 6. Quantitative reverse-transcriptase polymerase chain reaction primer sequences and efficiencies

\begin{tabular}{|c|c|c|c|}
\hline Gene name, ASAP ID number & Primer name & Primer sequence $\left(5^{\prime} \rightarrow 3^{\prime}\right.$, forward to reverse) & Efficiency $(\%)^{\mathrm{z}}$ \\
\hline \multirow[t]{2}{*}{ pect } & P0783 & TGGTGGTGCTGGATGAAC & \\
\hline & P0784 & GCGTAGAAGCGACATAAGAG & 100 \\
\hline \multirow[t]{2}{*}{ pelA } & P0767 & CTGCTGGCTACATTGATC & $\ldots$ \\
\hline & P0768 & AATTCACTGATATTGGTAACG & 99 \\
\hline \multirow[t]{2}{*}{ pelE } & P0769 & TCAGCATTCCGTCCAACAC & $\ldots$ \\
\hline & P0770 & GGCGTTCCAACCATCTCC & 90 \\
\hline \multirow[t]{2}{*}{ pelD } & P0771 & AAAGCAGCACTGAATGGC & \\
\hline & P0772 & CGATGATGGTGGTGTTGG & 95 \\
\hline \multirow[t]{2}{*}{ pelB } & P0773 & CTAAAGATGGCGATATGG & \\
\hline & P0774 & GATGTAGTTGTAGGATACG & 120 \\
\hline \multirow{2}{*}{ pelC } & P0775 & CAGGATGGCGATATGTTC & $\ldots$ \\
\hline & P0776 & CGTGGATGTTGTTGTAGG & 94 \\
\hline \multirow{2}{*}{ pelZ } & P0777 & TACGACTCCAGCCACTCC & $\ldots$ \\
\hline & P0778 & CAGGTTGCCGATGATTGC & 109 \\
\hline \multirow[t]{2}{*}{$p e l W$} & P0785 & CGTTATGTGCGGCTTGATG & $\ldots$ \\
\hline & P0786 & АCTTCCGACCATTTATTTCTGC & 96 \\
\hline \multirow[t]{2}{*}{ pelL } & P0763 & CGGCAATCATCGCATTACC & $\ldots$ \\
\hline & P0764 & GTTACAGAAGCAGACAGAGAC & 104 \\
\hline \multirow[t]{2}{*}{ pelI } & P0765 & TCAGGCTCAGGTCGTATC & . \\
\hline & P0766 & TCATTCGGACAGGAGGTG & 109 \\
\hline \multirow[t]{2}{*}{ pelX } & P0779 & AACAAACGCCGACCTTCC & $\ldots$ \\
\hline & P0780 & TCCTGATGGGTGACTAAATCC & 105 \\
\hline \multirow[t]{2}{*}{ ABF-0019391 } & P0781 & AAACACCGTCAATTACAG & $\ldots$ \\
\hline & P0782 & AATTCAGTATCGGAAATCG & 86 \\
\hline \multirow{2}{*}{$\operatorname{avrL}$} & P0783 & CAGAACACCACCGATCCAATCAG & $\ldots$ \\
\hline & P0784 & CGCCCAATCACCGAAGAAGTC & 101 \\
\hline \multirow[t]{2}{*}{$r p l U$} & P0275 & GTTTGACCAGGTTCTGATGGTTGC & $\ldots$ \\
\hline & P0276 & CCAGCCTGCTTACGGTAGTGTTTA & 91 \\
\hline \multirow[t]{2}{*}{ gyrA } & P0791 & CCACCCGTATCCCGAATC & $\ldots$ \\
\hline & P0792 & ACAACCGTCAATCACTTCAG & 90 \\
\hline \multirow[t]{2}{*}{ rpos } & P0789 & CGCTGCTGGATCTGATTG & $\ldots$ \\
\hline & P0790 & ACGATATGGATGGGTAAACG & 109 \\
\hline \multirow[t]{2}{*}{ oтpA } & P0787 & CAGACAGCCACGACAACTC & $\ldots$ \\
\hline & P0788 & TAGCGTATTCAACACCCACAG & 87 \\
\hline
\end{tabular}

\footnotetext{
${ }^{\mathrm{z}}$ Primer efficiencies were determined from the dilution curve using the MyiQ Cycler software
} 
at $25^{\circ} \mathrm{C}$ for $5 \mathrm{~min}, 42^{\circ} \mathrm{C}$ for $30 \mathrm{~min}$, and $85^{\circ} \mathrm{C}$ for $5 \mathrm{~min}$, and the cDNA was stored at $4^{\circ} \mathrm{C}$.

Expression of mRNA was analyzed by quantitative real-time PCR using the MyiQ detection system (Bio-Rad Laboratories). Samples were performed in triplicate in $25-\mu$ l reactions; 12.5 $\mu l$ of iQ SYBR Green Supermix (Bio-Rad Laboratories), 0.2 $\mu \mathrm{M}$ forward and reverse primer, and $11.5 \mu \mathrm{l}$ of 1:10 diluted cDNA sample. Target gene abundance was initially normalized to combinations of three of four internal reference transcripts (rplU, gyrA, rpoS, or ompA) which were shown to be invariant using BestKeeper (Pfaffl et al. 2004). For later experiments, only $r p o S$ and gyrA were used because the four references were behaving similarly and we found that inclusion of a third reference did not affect data interpretation. The RER was calculated as the difference between the $C_{t}$ values and was determined using the equation $2^{-\Delta \Delta \mathrm{Ct}}$ as previously modified (Pfaffl 2001; Rotenberg et al. 2006). PCR conditions were $95^{\circ} \mathrm{C}$ for 3 min; 40 cycles of $95^{\circ} \mathrm{C}$ for $10 \mathrm{~s}$ and $50^{\circ} \mathrm{C}$ for $45 \mathrm{~s}$; and 1 cycle of $95^{\circ} \mathrm{C}$ for $1 \mathrm{~min}$ and $55^{\circ} \mathrm{C}$ for $1 \mathrm{~min}$; followed by a dissociation curve with 80 cycles of $55^{\circ} \mathrm{C}$ for $10 \mathrm{~s}$ with a $0.5^{\circ} \mathrm{C}$ increase per cycle. The dissociation (Melt) curve performed with each assay certified the absence of primer-dimers and the presence of a single product from each primer reaction. To assure PCR accuracy, PCR reaction products were sequenced directly and compared with the expected target sequence.

For each gene, RNA was isolated from three cultures of the wild type and three cultures of the fliA mutant. Two cDNA reactions were prepared per culture for a total of six cDNA reactions. Two RT-PCR reactions were prepared per cDNA for a total of 12 RT-PCR assays per strain. Genes found to be statistically different with these 12 RT-PCR data points were analyzed a second time as described above to confirm the results. Statistical analysis of RER values was performed with GraphPad Prism software using the unpaired two-tailed $t$ test function (GraphPad Software, Inc). Data from all cultures tested were combined for these analyses.

\section{ACKNOWLEDGMENTS}

This research was supported by United States Department of Agriculture (USDA) NRI program grant 2006-35319-17396 and USDA Hatch grant WIS01072 to A. O. Charkowski. This project made use of sequences from the $D$. dadantii 3937 genome project supported by Initiative for $\mathrm{Fu}$ ture Agriculture and Food Systems grant number 2001-52100-11316 to N. Perna from the USDA Cooperative State Research, Education, and Extension Service. We thank T. Mohan and J. J. Hawley for technical support, N. Perna and J. Apodaca for thoughtful discussions, and the reviewers for the many improvements they suggested.

\section{LITERATURE CITED}

Allison, C., and Hughes, C. 1991. Bacterial swarming-an example of prokaryotic differentiation and multicellular behavior. Sci. Prog. 75:403-422.

Anderson, L., and Seilhamer, J. 1997. A comparison of selected mRNA and protein abundances in human liver. Electrophoresis 18:533-537.

Arora, S. K., Ritchings, B. W., Almira, E. C., Lory, S., and Ramphal, R. 1998. The Pseudomonas aeruginosa flagellar cap protein, FliD, is responsible for mucin adhesion. Infect. Immun. 66:1000-1007.

Barak, J. D., Gorski, L., Naraghi-Arani, P., and Charkowski, A. O. 2005. Salmonella enterica virulence genes are required for bacterial attachment to plant tissue. Appl. Environ. Microbiol. 71:5685-5691.

Barak, J. D., Jahn, C. E., Gibson, D. L., and Charkowski, A. O. 2007. The role of cellulose and $\mathrm{O}$-antigen capsule in the colonization of plants by Salmonella enterica. Mol. Plant-Microbe Interact. 20:1083-1091.

Barras, F., Van Gijsegem, F., and Chatterjee, A. K. 1994. Extracellular enzymes and pathogenesis of soft rot Erwinia. Annu. Rev. Phytopathol. 32:210-234.

Bell, K. S., Sebaihia, M., Pritchard, L., Holden, M. T. G., Hyman, L. J., Holeva, M. C., Thomson, N. R., Bentley, S. D., Churcher, L. J. C., Mungall, K., Atkin, R., Bason, N., Brooks, K., Chillingworth, T., Clark,
K., Doggett, J., Fraser, A., Hance, Z., Hauser, H., Jagels, K., Moule, S., Norbertczak, H., Ormond, D., Price, C., Quail, M. A., Sanders, M., Walker, D., Whitehead, S., Salmond, G. P. C., Birch, P. R. J., Parkhill, J., and Toth, I. K. 2004. Genome sequence of the enterobacterial phytopathogen Erwinia carotovora subsp. atroseptica and characterization of virulence factors. Proc. Natl. Acad. Sci. U.S.A. 101:11105-11110.

Burkart, M., Toguchi, A., and Harshey, R. M. 1998. The chemotaxis system, but not chemotaxis, is essential for swarming motility in Escherichia coli. Proc. Natl. Acad. Sci. U.S.A. 95:2568-2573.

Chatterjee, A., Cui, Y., Liu, Y., Dumenyo, C. K., and Chatterjee, A. K. 1995. Inactivation of rsmA leads to overproduction of extracellular pectinases, cellulase, and proteases in Erwinia carotovora subsp. carotovora in the absence of the starvatio/cell density-sensing signal, N-(3-oxohexanoyl)-Lhomoserine lactone. Appl. Environ. Microbiol. 61:1959-1967.

Chesnokova, O., Coutinho, J. B., Khan, I. H., Mikhail, M. S., and Kado, C. I. 1997. Characterization of flagella genes of Agrobacterium tumefaciens, and the effect of a bald strain on virulence. Mol. Microbiol. 23:579-590.

Chilcott, G. S., and Hughes, K. T. 2000. Coupling of flagellar gene expression to flagellar assembly in Salmonella enterica serovar typhimurium and Escherichia coli. Microbiol. Mol. Biol. Rev. 64:694-708.

Chinchilla, D., Bauer, Z., Regenass, M., Boller, T., and Felix, G. 2006. The Arabidopsis receptor kinase FLS2 binds flg22 and determines the specificity of flagellin perception. Plant Cell 18:465-476.

Claret, L., Miquel, S., Vieille, N., Ryjenkov, D. A., Gomelsky, M., and Darfeuille-Michaud, A. 2007. The flagellar sigma factor FliA regulates adhesion and invasion of Crohn disease-associated Escherichia coli via a cyclic dimeric GMP-dependent pathway. J. Biol. Chem. 282:3327533283.

Collmer, A., Reid, J. L., and Mount, M. S. 1988. Assay methods for pectic enzymes. Methods Enzymol. 161:329-335.

Condemine, G., Castillo, A., Passeri, F., and Enard, C. 1999. The PecT repressor coregulates synthesis of exopolysaccharides and virulence factors in Erwinia chrysanthemi. Mol. Plant-Microbe Interact. 12:45-52.

Datsenko, K. A., and Wanner, B. L. 2000. One-step inactivation of chromosomal genes in Escherichia coli K-12 using PCR products. Proc. Natl. Acad. Sci. U.S.A. 97:6640-6645.

De Boer, S. H., and Kelman, A. 2001. Erwinia soft rot group. Pages 56-72 in: Laboratory Guide for Identification of Plant Pathogenic Bacteria. N. W. Schaad, J. B. Jones, and W. Chun, eds. American Phytopathological Society Press, St. Paul, MN, U.S.A.

Eichelberg, K., and Galan, J. E. 2000. The flagellar sigma factor fliA $\left(\sigma^{28}\right)$ regulates the expression of Salmonella genes associated with the centisome 63 type III secretion system. Infect. Immun. 68:2735-2743.

Enard, C., Diolez, A., and Expert, D. 1988. Systemic virulence of Erwinia chrysanthemi 3937 requires a functional iron assimilation system. J. Bacteriol. 170:2419-2426.

Felix, G., Duran, J. D., Volko, S., and Boller, T. 1999. Plants have a sensitive perception system for the most conserved domain of bacterial flagellin. Plant J. 18:265-276.

Fraser, G. M., and Hughes, C. 1999. Swarming motility. Curr. Opin. Microbiol. 2:630-635.

Glanemann, C., Loos, A., Gorret, N., Willis, L. B., O’Brien, X. M., Lessard, P. A., and Sinskey, A. J. 2003. Disparity between changes in mRNA abundance and enzyme activity in Corynebacterium glutamicum: Implications for DNA microarray analysis. Appl. Microbiol. Biotechnol. 61:61-68.

Glasner, J. D., Liss, P., Plunkett, G., Darling, A., Prasad, T., Rusch, M., Byrnes, A., Gilson, M., Biehl, B., Blattner, F. R., and Perna, N. T. 2003. ASAP, a systematic annotation package for community analysis of genomes. Nucleic Acids Res. 31:147-151.

Glasner, J. D., Rusch, M., Liss, P., Plunkett, G., 3rd, C., E. L., Darling, A., Anderson, B. D., Infield-Harm, P., Gilson, M. C., and Perna, N. T. 2006. ASAP: A resource for annotating, curating, comparing, and disseminating genomic data. Nucleic Acids Res. 34:D41-45.

Gomez-Gomez, L., and Boller, T. 2002. Flagellin perception: A paradigm for innate immunity. Trends Plant Sci. 7:251-256.

Gygi, S. P., Rochon, Y., Franza, B. R., and Aebersold, R. 1999. Correlation between protein and mRNA abundance in yeast. Mol. Cell. Biol. 19:1720-1730.

Harshey, R. M. 1994. Bees aren't the only ones-Swarming in gram-negative bacteria. Mol. Microbiol. 13:389-394.

Harshey, R. M. 2003. Bacterial motility on a surface: Many ways to a common goal. Annu. Rev. Microbiol. 57:249-273.

Hayashi, F., Smith, K. D., Ozinsky, A., Hawn, T. R., Yi, E. C., Goodlett, D. R., Eng, J. K., Akira, S., Underhill, D. M., and Aderem, A. 2001. The innate immune response to bacterial flagellin is mediated by Toll-like receptor 5. Nature 410:1099-1103.

Hirano, S. S., Osterag, E. M., Savage, S. A., Baker, L. S., Willis, D. K., and Upper, C. D. 1997. Contribution of the regulatory gene lemA to 
field fitness of Pseudomonas syringae pv. syringae. Appl. Environ. Microbiol. 63:4304-4312.

Horne, S. M., and Pruss, B. M. 2006. Global gene regulation in Yersinia enterocolitica: Effect of FliA on the expression levels of flagellar and plasmid-encoded virulence genes. Arch. Microbiol. 185:115-126.

Ide, N., Ikebe, T., and Kutsukake, K. 1999. Reevaluation of the promoter structure of the class 3 flagellar operons of Escherichia coli and Salmonella. Genes Genet. Syst. 74:113-116.

Jahn, C. E., Charkowski, A. O., and Willis, D. K. Evaluation of isolation methods and RNA integrity for bacterial RNA quantitation. J. Microbiol. Meth. In press.

Julkowska, D., Obuchowski, M., Holland, I. B., and Seror, S. J. 2004. Branched swarming patterns on a synthetic medium formed by wildtype Bacillus subtilis strain 3610: Detection of different cellular morphologies and constellations of cells as the complex architecture develops. Microbiology 150:1839-1849.

Kazemi-Pour, N., Condemine, G., and Hugouvieux-Cotte-Pattat, N. 2004. The secretome of the plant pathogenic bacterium Erwinia chrysanthemi. Proteomics 4:3177-3186.

Koutsoudis, M. D., Tsaltas, D., Minogue, T. D., and von Bodman, S. B 2006. Quorum-sensing regulation governs bacterial adhesion, biofilm development, and host colonization in Pantoea stweartii subspecies stewartii. Proc. Natl. Acad. Sci. U.S.A. 103:5983-5988.

Lemattre, M., and Narcy, J. P. 1972. Une infection bacterienne nouvelle du Saintpaulia due a Erwinia chrysanthemi. C. R. Acad. Sci. 58:227-231.

Llama-Palacios, A., Lopez-Solanilla, E., Poza-Carrion, C., GarciaOlmedo, F., and Rodriguez-Palenzuela, P. 2003. The Erwinia chrysanthemi phoP-phoQ operon plays an important role in growth at low $\mathrm{pH}$, virulence and bacterial survival in plant tissue. Mol. Microbiol. 49:347357.

Lopez-Solanilla, E., Garcia-Olmedo, F., and Rodriguez-Palenzuela, P. 1998. Inactivation of the sapA to sapF locus of Erwinia chrysanthemi reveals common features in plant and animal bacterial pathogenesis. Plant Cell 10:917-924.

Ma, B., Hibbing, M. E., Kim, H. S., Reedy, R. M., Yedidia, I., Breuer, J., Glasner, J. D., Perna, N. T., Kelman, A., and Charkowski, A. O. 2007. Host range and molecular Phylogenies of the soft rot enterobacterial genera Pectobacterium and dickeya. Phytopathology 97:1150-1163.

Macnab, R. M. 1996. Flagella and Motility. ASM Press, American Society for Microbiology, Washington, D.C.

Moline, H. E., and Kulik, M. M. 1997. Contamination and deterioration of alfalfa sprouts caused by a seedborne isolate of Erwinia herbicola. J. Food Qual. 20:53-60.

Morden, C. W., Wolfe, K. H., Claude, W. D., and Pamler, J. D. 1991. Plastid translation and transcription genes in a non-photosynthetic plant: Intact, missing and pseudogenes. EMBO (Eur. Mol. Biol. Organ.) J. 10:3281-3288.

Mulholland, V., Hinton, J. C. D., Sidebotham, J., Toth, I. K., Hyman, L. J., Perombelon, M. C. M., Reeves, P. J., and Salmond, G. P. C. 1993. A pleiotropic reduced virulence (Rvi-) mutant of Erwinia carotovora subspecies atroseptica is defective in flagella assembly proteins that are conserved in plant and animal bacterial pathogens. Mol. Microbiol. 9:343-356.

Nagel, C. W., and Anderson, M. M. 1965. Action of a bacterial transeliminase on normal and unsaturated oligogalacturnoic acids. Arch. Biochem. Biophys. 112:322-

Nasser, W., Bouillant, M. L., Salmond, G., and Reverchon, S. 1998. Characterization of the Erwinia chrysanthemi expI-expR locus directing the synthesis of two N-acyl-homoserine lactone signal molecules. Mol. Microbiol. 29:1391-1405.

Nasser, W., Reverchon, S., Vedel, R., and Boccara, M. 2005. PecS and PecT coregulate the synthesis of HrpN and pectate lyases, two virulence determinants in Erwinia chrysanthemi 3937. Mol. Plant-Microbe Interact. 18:1205-1214.

Niu, C., Graves, J. D., Mokuolu, F. O., Gilbert, S. E., and Gilbert, E. S. 2005. Enhanced swarming of bacteria on agar plates containing the surfactant Tween 80. J. Microbiol. Methods 62:129-132.

O'Toole, G. A., and Kolter, R. 1998. Flagellar and twitching motility are necessary for Pseudomonas aeruginosa biofilm development. Mol. Microbiol. 30:295-304.

Okinaka, Y., Yang, C. H., Perna, N. T., and Keen, N. T. 2002. Microarray profiling of Erwinia chrysanthemi 3937 genes that are regulated during plant infection. Mol. Plant-Microbe Interact. 15:619-629.

Panopoulos, N. J., and Schroth, M. N. 1974. Role of flagellar motility in invasion of bean leaves by Pseudomonas phaseolicola. Phytopathology
64:1389-1397.

Parker, J. E., Barber, C. E., Fan, M. J., and Daniels, M. J. 1993. Interaction of Xanthomonas campestris with Arabidopsis thaliana-Characterization of a gene from $X$. c. pv. Raphani that confers avirulence to most $A$. thaliana accessions. Mol. Plant-Microbe Interact. 6:216-224.

Persmark, M., Expert, D., and Neilands, J. B. 1989. Isolation, characterization, and synthesis of chrysobactin, a compound with siderophore activity from Erwinia chrysanthemi. J. Biol. Chem. 264:3187-3193.

Persmark, M., Expert, D., and Nielsen, J. L. 1992. Ferric iron uptake in Erwinia chrysanthemi mediated by chrysobactin and related catecholtype compounds. J. Bacteriol. 174:4783-4789.

Pfaffl, M. W. 2001. A new mathematical model for relative quantification in real-time RT-PCR. Nucleic Acids Res. 29.

Pfaffl, M. W., Tichopad, A., Prgomet, C., and Neuvians, T. P. 2004. Determination of stable housekeeping genes, differentially regulated target genes and sample integrity: BestKeeper-Excel-based tool using pairwise correlations. Biotechnol. Lett. 26:509-515.

Pierce, L., and McCain, A. H. 1985. Alfalfa sprout rot caused by Erwinia chrysanthemi. (Abstr.) Phytopathology 75:1379.

Reverchon, S., Nasser, W., and Robertbaudouy, J. 1994. Pecs: A locus controlling pectinase, cellulase and blue pigment production in Erwinia chrysanthemi. Mol. Microbiol. 11:1127-1139.

Ried, J. L., and Collmer, A. 1987. Construction and analysis of an Erwinia chrysanthemi mutant containing deletions in the pel genes encoding all of the major pectate lyase isozymes. Phytopathology 77:1719-1719.

Rotenberg, D., Thompson, T. S., German, T. L., and Willis, D. K. 2006. Methods for effective real-time RT-PCR analysis of virus-induced gene silencing. J. Virol. Methods 138:49-59.

Sambrook, J., and Russell, D. W. 2001. Molecular Cloning: A Laboratory Manual. Cold Spring Harbor Laboratory Press, Cold Spring Harbor, NY, U.S.A.

Schoonejans, E., Expert, D., and Toussaint, A. 1987. Characterization and virulence properties of Erwinia chrysanthemi lipopolysaccharide-defective, phiec2-resistant mutants. J. Bacteriol. 196:4011-4017.

Shapiro, J. A. 1998. Thinking about bacterial populations as multicellular organisms. Annu. Rev. Microbiol. 52:81-104.

Shevchik, V. E., Condemine, G., Robert-Baudouy, J., and HugouvieuxCote-Pattat, N. 1999. The exopolygalacturonate lyase PelW and the oligogalacturonate lyase Ogl, two cytoplasmic enzymes of pectin catabolism in Erwinia chrysanthemi 3937. J. Bacteriol. 181:3912-3919.

Sun, W. X., Dunning, F. M., Pfund, C., Weingarten, R., and Bent, A. F. 2006. Within-species flagellin polymorphism in Xanthomonas campestris pv. campestris and its impact on elicitation of Arabidopsis FLAGELLIN SENSING2-dependent defenses. Plant Cell 18:764-779.

Surgey, N., Robert-Baudouy, J., and Condemine, G. 1996. The Erwinia chrysanthemi pecT gene regulates pectinase gene expression. J. Bacteriol. 178:1593-1599.

Tans-Kersten, J., Huang, H. Y., and Allen, C. 2001. Ralstonia solanacearum needs motility for invasive virulence on tomato. J. Bacteriol. 183:3597-3605.

Wachtel, M. R., and Charkowski, A. O. 2002. Cross-contamination of lettuce with Escherichia coli O157 : H7. J. Food Prot. 65:465-470.

Willis, D. K., Hrabek, E. M., Rich, J. J., Barta, T. M., Lindow, S. E., and Panapoulos, N. J. 1990. Isolation and characterization of a Pseudomonas syringae pv. syringae mutant deficient in lesion formation on bean. Mol. Plant-Microbe Interact. 3:149-156.

Yang, S. H., Zhang, Q., Guo, J. H., Charkowski, A. O., Glick, B. R., Ibekwe, A. M., Cooksey, D. A., and Yang, C. H. 2007. Global effect of indole-3-acetic acid biosynthesis on multiple virulence factors of $\mathrm{Er}$ winia chrysanthemi 3937. Appl. Environ. Microbiol. 73:1079-1088.

Yang, S. H., Peng, Q., Zhang, Q., Yi, X., Choi, C. J., Reedy, R. M., Charkowski, A. O., and Yang, C. H. 2008. Dynamic regulation of GacA in type III secretion, pectinase gene expression, pellicle formation, and pathogenicity of Dickeya dadantii (Erwinia chrysanthemi 3937). Mol. Plant-Microbe Interact. 21:133-142.

Yap, M.-N., Yang, C. H., Barak, J. D., Jahn, C. E., and Charkowski, A. O. 2005. The Erwinia chrysanthemi type III secretion system is required for multicellular behavior. J. Bacteriol. 187:639-648.

Yap, M.-N., Yang, C. H., and Charkowski, A. O. 2008. The response regulator HrpY of Dickeya dadantii 3937 regulates virulence genes not linked to the hrp cluster. Mol. Plant-Microbe Interact. 21:304-314.

Yi, T. M., Huang, Y., Simon, M. I., and Doyle, J. 2000. Robust perfect adaptation in bacterial chemotaxis through integral feedback control. Proc. Natl. Acad. Sci. U.S.A. 97:4649-4653. 